\title{
N-Terminal Parathyroid Hormone Measurement
}

National Cancer Institute

\section{Source}

National Cancer Institute. N-Terminal Parathyroid Hormone Measurement. NCI

Thesaurus. Code C81966.

The determination of the amount of $\mathrm{N}$-terminal parathyroid hormone present in a sample. 